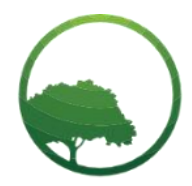

Research in Business \& Social Science

IJRBS VOL 10 NO 3 ISSN: 2147-4478

\title{
The effect of philanthropic organizations' culture on employee performance through organizational commitment and organization citizenship behavior as intervening variables
}

\author{
(D) Taufiqurrahman ${ }^{(a) *(D)}$ Noermijati $^{(b)}$ (D) Desi Tri Kurniawati ${ }^{(c)}$ \\ ${ }^{(a)}$ Management Department, Faculty of Economic and Business, Universitas Brawijaya, Malang, Indonesia \\ (b) Professor, Management Department, Faculty of Economic and Business, Universitas Brawijaya, Malang, Indonesia \\ (c) Ph.D. Management Department, Faculty of Economic and Business, Universitas Brawijaya, Malang, Indonesia
}

\begin{tabular}{l} 
A R T I C L E I N F O \\
\hline Article history: \\
Received 11 March 2021 \\
Received in rev. form 08 April 2021 \\
Accepted 12 April 2021 \\
Keywords: \\
Organizational Culture, \\
Organizational Commitment, \\
Organizational Citizenship Behavior \\
(OCB), Employee Performance \\
JEL Classification: \\
G31, G23
\end{tabular}

\begin{abstract}
A B S T R A C T
The purpose of this study is to explain and analyze the effect of organizational culture on employee performance by mediating organizational commitment and Organizational Citizenship Behavior $(O C B)$ in Philanthropic Organizations in Malang Raya. This research is a quantitative study with data collection methods using a questionnaire. The population in this study is 154 employees from 10 philanthropic organizations in Malang Raya. The sample was selected This study uses probability sampling with a saturated sampling type. From 115 returned questionnaires. the collected data was then analyzed using SEM (Structural Equation Modeling) PLS. The results showed that the organization culture variables had a positive and significant impact on employee performance. Besides, the results of this study also show that two mediating variables have different effects. OCB has a positive and significant effect on employee performance, while organizational commitment does not affect employee performance. Based on the results of mediation testing, it shows that OCB provides a partial mediation on the effect of organizational culture on employee performance. This study also shows that organizational commitment can not mediate organizational culture on employee performance. The implications of the research findings are expected to be fed into the Malang Raya Philanthropic Organization to maximize potential.
\end{abstract}

(C) 2021 by the authors. Licensee SSBFNET, Istanbul, Turkey. This article is an open access article distributed under the terms and conditions of the Creative Commons Attribution (CC BY) license (http://creativecommons.org/licenses/by/4.0/).

\section{Introduction}

Currently, there is an association of philanthropic organizations in Indonesia, namely Filantropi Indonesia, which consists of 47 foundations, 2 communities, 6 associations, and 1 research/academic institute. As an organization engaged in social philanthropic activities, philanthropic organizations can survive and develop in the national and even international sphere. The broad scope of work provides opportunities for people to help others, regardless of geographical reach. With rising inequality, economic, social, and natural disasters, the role of non-discriminatory philanthropic organizations oriented toward real problems is becoming increasingly important.

Basically, the concept of generosity (philanthrophy) has long been known and practiced by every ethnic culture and religious community in various parts of the world. In Indonesia, the need for philanthropic organizations is inseparable from the condition of a society that has an eastern collective culture that emphasizes mutual tolerance and mutual ownership and the majority of the $85 \%$ Muslim population who have teachings to carry out generosity in the form of zakat, infaq, sadaqah and endowments. This demands well-organized management. According to the 2019 National Zakat Statistics issued by BAZNAZ, the average growth of five-year zakat collection at $25.7 \%$ indicates that the Indonesian people, known for their hospitality and generosity, are increasingly familiar and aware of the obligation to give zakat, to share with those in need.

* Corresponding author. ORCID ID: 0000-0002-1306-6530

(c) 2021 by the authors. Hosting by SSBFNET. Peer review under responsibility of Center for Strategic Studies in Business and Finance. https://doi.org/10.20525/ijrbs.v10i3.1124 
Although social situations are very supportive for growth, the journey of philanthropic organizations is still very far away. There is still a gap between the realization and potential of philanthropy in Indonesia. Based on the calculation of the component of the Zakat Potential Mapping Indicator (IPPZ) and the 2019 Indonesian Zakat Outlook, the zakat potential is IDR 233.8 trillion (equivalent to 1.72 percent of GDP in 2017) and based on the latest report from BAZNAZ in 2019, the collected zakat is IDR 10.2 trillion or $4.36 \%$ of zakat potential. Therefore, philanthropic institutions must continuously improve the quality of institutions and human resources to optimize their potential.

Important factors that can improve employee performance of philanthropic organizations optimally and continuously must be considered. Smircich (1983) argues that organizational culture is an important element that can be utilized by leaders to direct their organizations in the right direction. Organizational culture can create collective meanings that form the basis of how organizational members communicate and understand each other (Furnham \& Gunter, 1993). A strong organizational culture can affect coordination and control within the organization, better alignment of goals between the organization and its members, and increased employee employment (Kotter and Heskett, 1992).

As an internal environmental factor that affects human resource management, organizational culture refers to the social and psychological climate of the company (Mondy \& Martocchio, 2016: 35). Values, beliefs, and behaviors will be guided by an organizational culture that has an impact on employee satisfaction and performance quality. Armstrong (2009: 384) explains that the patterns of values, beliefs and attitudes of individuals formed in an organizational culture are able to shape their behavior through unwritten rules so as to direct them to behavior that leads to performance. Organizational culture can be an important variable for the development of philanthropic organizations' human resources.

There are inconsistent research results about the relationship between organization culture and employee performance. Previous research shows that organizational culture can affect employee performance positively and significantly (Karinda, 2016; Shahzad et al, 2017; Aboramadan et al, 2019; Tan, 2019). The better the organizational culture is formed, the better employee performance is. Various research results confirm that organizational culture has a positive effect on employee performance. On the other hand, Putriana (2015) and Kurniasari (2018) prove that organizational culture has not been able to significantly improve employee performance.

To fill the gap, it is necessary to have a mediating variable. This will be examined more deeply with the mediating variables of organizational commitment and OCB. Adam et al. (2020) stated that organizational commitment can be a mediating variable between organization culture and performance. Supriyadi et al (2017) stated that OCB can positively and significantly play a role as a mediator for the relationship between organization culture and employee performance.

Virtanen (2000) asserts that a strong organization culture can be conceptualized as a strong organizational commitment. Characteristics of organizational culture such as corporate values and beliefs can be associated with organizational commitment and performance (Harrison, 1972; Peters and Waterman, 1982; Trice and Beyer, 1993). A strong match between individual value preferences and organizational values is believed to result in strong employee commitment. Research on organizational culture on commitment is explained by Al-Sada (2017), Raharjo et al (2018), Shim (2015) and Jain (2015) which explain that organizational culture has a positive influence on employee organizational commitment. An empirical study of the relationship between organizational commitment and performance is shown by research by Oyewobi et al (2019), Chiu et al (2019), Franco and Franco (2017).

O'Reilly and Chatman (1996) argue that culture acts as a social control mechanism. Organizational culture helps in creating a tendency to develop certain attitudes and behaviors, for example, feelings of attachment or detachment from the organization, and pro-social or antisocial behavior. This affects the development of relationships between individuals so that it motivates employees to form high OCBs, even when no financial returns are obtained.

Harwiki (2016) shows that organizational culture has a significant impact on OCB and plays a full role in mediating performance. The results of Wandary and Anisah's (2015) research on lecturers of one university show a relatively strong relationship between organizational culture and OCB. Supported by Ghashghaeinia and Hafezi (2015) who researched on Azad University staff, it also showed that there was a significant positive relationship between organizational culture and OCB. Empirical research that shows the relationship between OCB and performance is described by Kissi et al (2019), Dharma (2018), Munawir et al (2019) and Sani and Maharani (2019).

Philanthropic organizations have a different orientation from business organizations and are not like public service agencies which generally receive financial support from the government. In an era of increasingly fierce competition that demands more value in the form of salaries, benefits, facilities, and career opportunities, philanthropic organizations survive with their distinctive generosity as a value in managing their human resources. The value of generosity, which is at the core of philanthropic organizations, does not hinder development and growth, but even becomes excellence. The vision and mission that the organization carries can inspire not only internally but also get a positive response from the community. These values form an organizational culture that guides in carrying out human resource management.

The inconsistency of the results of research on organizational culture on performance attempts to be explained by proposing OCB variables and organizational commitment as mediation and philanthropic organizations as research objects that have the characteristic 
value of generosity. Human Resources research on philanthropic organizations has received less attention because it tends to focus on companies or public agencies. Based on the observation of phenomena, several theories and empirical facts that have been described above, this study analyzes the influence of organizational culture on organizational performance mediated by organizational commitment and Organizational Citizenship Behavior (OCB).

\section{Literature Review}

\section{Organization Culture}

Culture cannot be separated from the community or organization. How social relationships and interactions with each other in a community or organization produce a prevailing culture. It is built on common interests and shared obligations carried out by all members. Culture is a unique characteristic of human groups created to fulfill the basic need to find common meanings from the events around them. Dessler (2013: 466) defines organizational culture as the characteristic values, traditions, and behaviors possessed by employees.

Goffee and Jones (1996) use sociability and solidarity as indicators that determine organizational culture. From these two dimensions, it produces four types of organizational culture, namely networked, mercenary, fragmented, and communal. Neither of these cultures is the "best." So there needs to be an assessment of the internal organization and the competitive situation in order to determine the optimal culture to apply. In the case of non-profit organizations based on religion, politics, and civil society, the higher the sociability and solidarity, the better that these two indicators are relevant to measuring the organizational culture of philanthropic organizations.

\section{Empirical Studies}

A strong organizational culture can affect coordination and control within the organization, better alignment of goals between the organization and its members, and increased employee employment (Kotter and Heskett, 1992). Previous research has shown the influence of organizational culture on employee performance (Karinda, 2016; Shahzad et al, 2017; Aboramadan et al, 2019; Tan, 2019). Organizational culture turns out to have an insignificant influence on employee performance based on research conducted by Putriana et al (2015) and Kurniasari (2018).

\section{Organizational Commitment}

Mathis and Jackson (2010: 158) explain that the definition of organizational commitment is the belief and acceptance of employees towards organizational goals and their desire to remain in the organization. In line with this definition, Armstrong (2014: 336) defines organizational commitment as referring to attachment and loyalty. He added that organizational commitment can be seen through three characteristics of behavior, namely clarity of action, seriousness in completing work, and voluntary action.

Mowdays et al (1982: 46) define organizational commitment with three behavioral characteristics, namely (1) a strong desire to remain a member of the organization; (2) willingness to exert effort on behalf of the organization; and (3) belief and acceptance of the values and goals of the organization. Organizational commitment is inseparable from being loyal to the values and goals of the organization and striving to achieve success for both the organization and the employees themselves. Kinicki and Kreitner (2014: 167) state that to increase employee commitment, there are indicators of affection for your job (affective commitment), fear of loss (continuance commitment), and a sense of obligation to stay (normative commitment).

\section{Empirical Studies}

The effect of organizational commitment on performance is explained by the research of Oyewobi et al (2019), Chiu et al (2019), and Imamoglu et al (2019) who use structural equation modeling (PLS-SEM) as an analytical tool. Franco and Franco (2017) found that in family SMEs, affective commitment has a positive influence on contextual performance. Adam et al. (2020) research conclude that organizational commitment can mediate the improvement of employee performance.

\section{Organizational Citizenship Behavior (OCB)}

OCB is an individual's behavioral initiative that is not directly or explicitly recognized by a formal reward system that goes beyond task obligations and contributes to the effectiveness of organizational functions (Organ, 1988). It is employee behavior that goes beyond the duty obligation (extra-role) and contributes to the effectiveness of organizational functions. OCB has characteristics of voluntary behavior that are not included in job descriptions, helpful behavior and behavior that is not easily visible and is assessed through performance evaluation. Organ (1988: 6) states that there are five indicators of OCB that have been used as research references to date, namely altruism, Conscientiousness, Sportmanship, Courtesy, and Civic virtue.

\section{Empirical Studies}

The effect of OCB on performance is explained by research by Kissi et al (2019). Dharma (2018) and Sani (2019). Munawir (2018) researched universities that showed OCB affects the success of university governance and good performance. Research by Supriyadi et al (2017) states that OCB can positively and significantly play a role as a mediator for the relationship between organizational culture and employee performance. 


\section{Employee Performance}

Performance is defined as behavior and results (Armstrong, 2014: 331). Zablah et al (2012) define performance as the extent to which employees contribute to organizational effectiveness according to expectations associated with their job roles. High performance individuals are needed to achieve goals, increase productivity, and increase the competitiveness of an organization (Sonnentag \& Frese, 2002).

\section{Empirical Studies}

Koopmans et al (2014) developed a more valid instrument to measure employee performance, namely the Individual Work Performance Questionnaire 1.0 (IWPQ 1.0) which consists of task performance, contextual performance, and counterproductive work behavior). In this study, only 2 indicators were used, namely task performance and contextual performance. Indicators of counterproductive work behavior are irrelevant to the object of research, namely philanthropic organizations, because they include non-profit organizations that are not profit-oriented and have employee volunteer motives when joining philanthropic organizations.

\section{Research Framework and Hypothesis Formation}

This research observed four main constructs consisting of one exogenous (organization culture) and one endogenous (employee performance). Aside from that, we observed two mediation constructs (organization commitment and OCB). To be more clear, it can be seen in Figure 1.

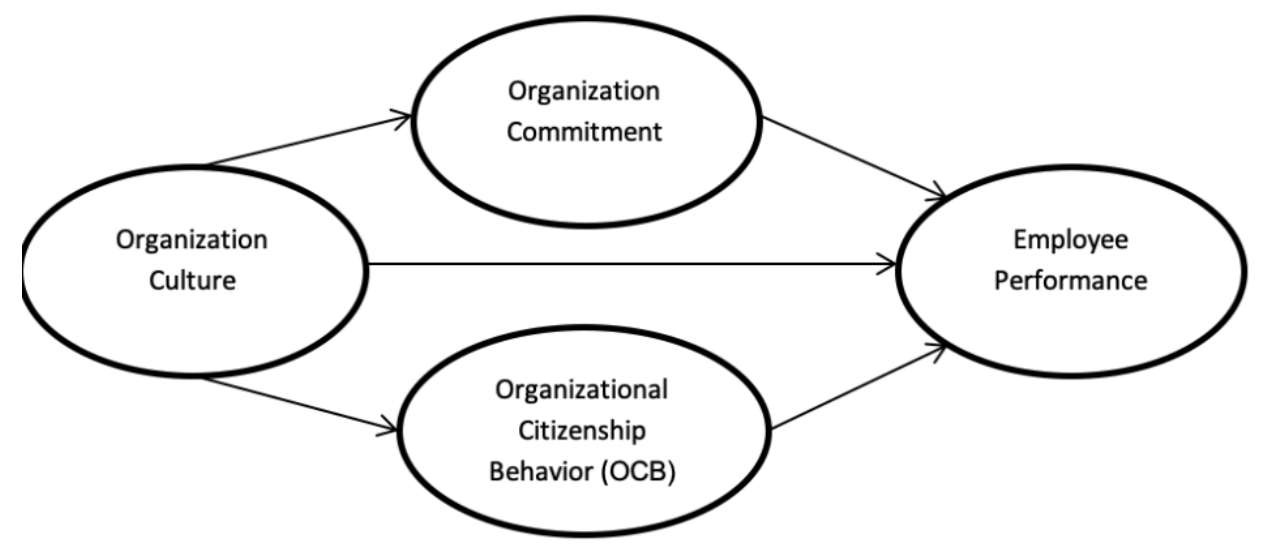

Figure 1: Research Framework and Hypothesis

The hypotheses of this study are:

H1: Organizational culture has a significant positive effect on employee performance.

H2: Organizational Culture has a Significant Positive Effect on Organizational Commitment

H3: Organizational Culture has a Significant Positive Effect on Employee OCB

H4: Organizational Commitment has a significant positive effect on employee performance

H5: OCB has a significant positive effect on employee performance

H6: Organizational Commitment Mediates the Influence of Organizational Culture on Employee Performance

H7: OCB Mediates the Influence of Organizational Culture on Employee Performance

\section{Research and Methodology}

\section{Participants and Data Collection}

The population in this study were all employees of 10 philanthropic organizations in Malang Raya, namely Yatim Mandiri Malang, Infaq Management Institute (LMI), Baitul Maal Hidayatullah (BMH) Malang, Aksi Cepat Tanggap (ACT), LAZISMU Malang City and Batu City, the Yayasan Dana Sosial Al-Falah (YDSF), LAZIS Sabilillah, BAZNAZ Malang City, and Badan Wakaf Alquran (BWA) Malang. The population of this research is 154 employees in philanthropic organizations in Malang Raya.

The sampling technique used census techniques, where all populations are used as research samples. Primary data was used in questionnaires. The study was conducted from October to December 2020. The number of questionnaires collected from the study were 115 questionnaires, $74 \%$ that were eligible for data processing. 


\section{Data Analysis}

The method of data analysis uses SEM (Structural Equation Modeling) based on Partial Least Square (PLS) that uses SmartPLS 3.3.2 software application.

\section{Measurement}

All indicators to measure the three variables were adopted from several previous studies. Organizational culture variables were adapted from a study conducted by Goffee and Jones (1996), which included two indicators, sosiability and solidarity. Organizational commitment variables were measured through 3 indicators from Kreitner and Kinicki (2014) which included affective commitment, continuous commitment and normative commitment. The OCB variable is measured through 5 indicators from Organ (2006), namely altruism, conscientiousness, sportsmanship, courtesy, and civic virtue. While indicators to measure employee performance variables used 2 indicators belonging to Koopmans et al (2015), namely task performance and contextual performance.

\section{Result and Discussion}

\section{Result}

Based on the results of the data processing, it is known that 32 respondents (28\%) were <25 years old, 40 respondents (35\%) were 25-37years old, 33 respondents $(29 \%)$ were $38-50$ years old and $10(9 \%)$ respondents were $50>$ years old. Based on gender, 83 respondents $(72 \%)$ were male and 32 respondents were female (28\%). According to the most recent education factor, 37 respondents (32\%) had a high school diploma, 74 respondents (65\%) had a bachelor's degree, and 4 respondents (3\%) had a master's degree. Furthermore, from the length of time employees worked there were 64 respondents $(56 \%)$ who had <5 years of service, 36 respondents $(31 \%)$ had worked for 5-10 years, and 15 respondents $(13 \%)$ had a working period of > 10 years.

Table 1: Cronbach Alpha, Composite Reliability, Average Variance

\begin{tabular}{llll}
\hline Variable & Cronbach Alpha & Composite Reliabiltiy & Average Variance \\
\hline Organization Culture & 0.921 & 0.932 & 0.501 \\
\hline Organizational Commitment & 0.874 & 0.900 & 0.506 \\
\hline OCB & 0.900 & 0.917 & 0.501 \\
\hline Employee Performance & 0.927 & 0.938 & 0.541 \\
\hline
\end{tabular}

Source: Processed primary data, 2021

The R-square values organizational commitment, OCB and employee performance variables of the research model are 0,405, 0,299 and 0,480 . Goodness of Fit (GoF) in this study was assessed by the following equation:

Average value AVE $=(0.501+0.506+0.501+0.541) / 4=0.512$

Average value $\mathrm{R} 2=(0.405+0.299+0.480) / 3=0.394$

$$
\begin{aligned}
G O F & =\sqrt{A V E \times R^{2}} \\
& =\sqrt{0.512 \times 0.394} \\
& =0.449
\end{aligned}
$$

0.449 indicates that the model has predictive relevance value for employee performance is explained by organization culture, organizational commitment, and OCB.

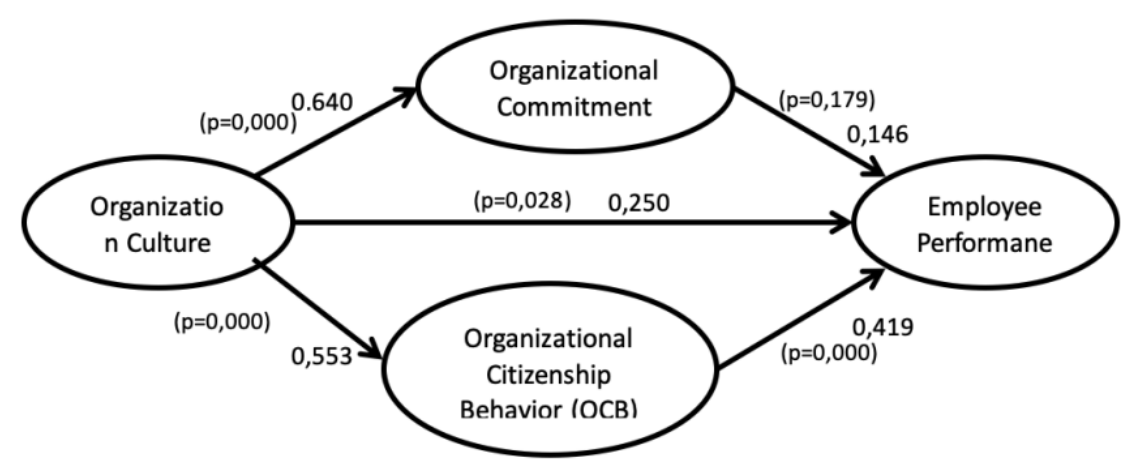

Figure 2: Direct Effect Testing Results; Source: Processed primary data, 2021 
Table 2: Mediation Test Result

\begin{tabular}{|c|c|c|c|c|c|}
\hline Variable & & $\begin{array}{l}\text { Path } \\
\text { Coefficient }\end{array}$ & $\begin{array}{l}\text { Standard } \\
\text { Deviation }\end{array}$ & $\begin{array}{l}\text { t- } \\
\text { statisti } \\
k\end{array}$ & $\begin{array}{l}\text { p- } \\
\text { values }\end{array}$ \\
\hline $\begin{array}{l}\text { Organization Culture-> Organizational Commitment } \\
\text { Employee Performance }\end{array}$ & $->$ & 0.093 & 0.074 & 1.256 & 0.210 \\
\hline Organization Culture -> OCB -> Employee Performance & & 0.232 & 0.058 & 3.964 & 0.000 \\
\hline
\end{tabular}

Source: Processed primary data, 2021

The direct influence presented in Figure 2, the impact of organization culture on employee performance was found to be significant with a path coefficient of 0.250 and p-value 0.028 (under the critical value of 0.05 ). Based on these findings, then hypothesis 1 is acceptable, which means that there is a significant and positive impact of organization culture on employee performance. Thus, hypothesis 1 is accepted.

The impact of organization culture on organizational commitment was found to be significant with a path coefficient of 0.640 and pvalue 0.000 (under the critical value of 0.05 ). Based on these findings, hypothesis 2 is accepted, implying that organizational culture has a significant and positive impact on organizational commitment. Thus, hypothesis 2 is accepted.

The impact of organization culture on OCB was found to be significant with a path coefficient of 0.553 and p-value 0.000 (under the critical value of 0.05). Based on these findings, then hypothesis 3 is acceptable, which means that there is a significant and positive impact of organization culture on OCB. Thus, hypothesis 3 is accepted.

The impact of organizational commitment on employee performance was found to be insignificant with a path coefficient of 0.146 and p-value 0,179 (above the critical value of 0.05). Based on these findings, then hypothesis 4 is rejected.

The impact of OCB on employee performance was found to be significant with a path coefficient of 0.419 and p-value 0.000 (under the critical value of 0.05). Based on these findings, then hypothesis 5 is acceptable, which means that there is a significant and positive impact of organization culture on OCB. Thus, hypothesis 5 is accepted.

The indirect influence presented in Tabel 2, the role of organizational commitment mediating the relationship between organization culture on employee performance, was found to be insignificant, with the path coefficient amounting to 0.093 and p-value 0.210 (above the critical value of 0.05); therefore, the hypothesis 2 was rejected. Thus, Hypotheses 6 is rejected.

The role of OCB mediating the relationship between organization culture and employee performance was found to be significant, with the path coefficient amounting to 0.232 and p-value 0.000 (under the critical value of 0.05 ); therefore, hypothesis 7 was accepted. Thus, Hypotheses 7 is accepted.

\section{Discussion}

The results of this study are consistent with previous research (Karinda, 2016; Shahzad et al, 2017; Aboramadan et al, 2019; Tan, 2019) that organizational culture has a significant positive effect on employee performance. The distinctive value of generosity in philanthropic organizations is able to form an organizational culture that influences employee performance improvement. Thus, the elements of organizational culture consisting of sociability and solidarity prove beneficial to organizational functions.

Undergraduate educational qualifications have soft skills that help to relate between employees and understand organizational goals so that they can support the forming of an optimal organizational culture. The results of this study are in accordance with research by Al-Sada et al (2017) which explains that organizational culture, especially in the education sector, has an influence on organizational commitment. Likewise, Jain (2015) in his research on the public sector shows organizational culture has a positive influence on affective commitment and sustainable commitment. This study emphasized Wandary and Anisah (2015) who conducted research on university lecturers and Ghashghaeinia and Hafezi (2015) on university staff. They stated that organizational culture has a strong relationship to OCB.

Organizational commitment in this result did not support employee performance as suggested by Setiawan (2020), Pinho et al (2014) and Eliyana et al (2019). This finding contradicts Oyewobi et al (2019), Chiu et al (2019), and Imamoglu et al (2019), who found a positive relationship between organizational commitment and organizational performance. The opportunity to develop and have a career can not be accommodated by philanthropic organizations that do not provide long-term careers. The absence of certainty guarantees in philanthropic organizations has an impact on the lack of a significant increase in performance.

The results of the research are in line with previous research studies (Kissi et al, 2019; Dharma, 2018; Munawir, 2018) which explain that OCB positively affects employee performance. Sani (2019) states that OCB from an Islamic perspective has an influence on performance. This relate to a philanthropic organization in Malang Raya with the value of generosity has a goal that requires a voluntary effort to take extra action beyond the job description.

Contrary to Adam et al. (2020), the result of the analysis proves that organizational commitment can not mediate the relationship between organization culture on employee performance. It means that organizational commitment cannot be stronger or lower the 
relationship between organization culture on employee performance of philanthropic organizations in Malang Raya. Lack of longterm opportunities in non-profit organizations makes organizational commitment of Philanthropy Employees in Malang Raya unable to become a significant variable in improving performance.

Based on the result of a mediation test on the seven hypothesis, it was proven that the variable of OCB was able to mediate the effect of organization culture to employee performance. This finding is in line with Supriyadi et al (2017) which states that OCB can positively and significantly play a role as a mediation for the relationship between organizational culture and employee performance. When the variable of organization culture was improved as well as the OCB on an employee was improved, employee performance would be increased. Furthermore, the OCB played a role of partial mediation, since the direct effect of organization culture was significantly influential employee performance.

\section{Conclusions}

This research finding shows interesting relationships between organization culture, OCB, organizational commitment, and employee performance. Organizational culture has a comprehensive role on impact OCB, organizational commitment, and employee performance because it has a positive and significant impact. Social relations between employees are built with sincere hospitality and organizational goals to be common goals can improve various aspects of emotional attachment, sense of responsibility, altruism, and task dan contextual performance. The need to form a strong organizational culture can be a consideration to improve the quality of human resources of the Philanthropic Organization in Malang Raya.

This study shows that organizational commitment in philanthropic organizations has no significant effect on employee performance. There is a lack of space for a long-term career in a philanthropic organization in Malang Raya that needs improvement. The majority of employees of productive age and who have a bachelor's degree still have opportunities to develop and long-term careers need to be facilitated. This is important to the sustainability of human resources in the philanthropic organization.

The result of this study show OCB has a significant effect on employee performance and participation as partial mediation of organizational culture on employee performance. The value of generosity has a goal that requires volunteerism in extra action beyond the job description. Employees who have high OCB elements can encourage them to play extra roles (extra roles) which will create a work attitude of employees who are responsible for achieving organizational goals. The philanthropic organizations must build strong OCB to development of human resources.

The distinctive value of the philanthropic organization in Malang Raya needs to be strengthened by carrying out an intense and periodic value orientation and conducting a campaign for the values of generosity. In an environment that prioritizes values in work, effective communication and teamwork is important. A strong organizational culture can improve the quality of human resources of philanthropic organizations.

This research has some limitations. This research has few suggestions that could be considered for future research:

i. The number of respondents in the study is limited to 10 philanthropic organizations in the Malang Raya region, so that further research is expected to be able to expand respondents so that they can broaden the generalization of research results.

ii. Conduct further research on the effect of organizational commitment on philanthropic organizations.

\section{References}

Aboramadan, M., Albashiti, B., Alharazin, H. and Zaidoune, S. (2019). Organizational culture, innovation and performance: a study from a non-western context. Journal of Management Development, 39(4), 437-451. https://doi.org/10.1108/JMD-06-20190253

Adam, A., Yuniarsih, T., Ahman, E. and Kusnendi, K. (2020). The Mediation Effect of Organizational Commitment in the Relation of Organization Culture and Employee Performance. In 3rd Global Conference On Business, Management, and Entrepreneurship (GCBME 2018), (260-264) https://doi.org/10.2991/aebmr.k.200131.056

Al-Sada, M., Al-Esmael, B. and Faisal, M. (2017). Influence of organizational culture and leadership style on employee satisfaction, commitment and motivation in the educational sector in Qatar. EuroMed Journal of Business, 12(2),163-188. https://doi.org/10.1108/EMJB-02-2016-0003

Armstrong, M., and Taylor, S. (2009). Armstrong's Handbook of Human Resource Management Practice. Kogan Page Publishers.

Carlos Pinho, J., Paula Rodrigues, A. and Dibb, S. (2014). The role of corporate culture, market orientation and organisational commitment in organisational performance. Journal of Management Development, 33(4),374-398. https://doi.org/10.1108/JMD-03-2013-0036

Chiu, W., Won, D. and Bae, J. (2019). Internal marketing, organizational commitment, and job performance in sport and leisure services. Sport, Business and Management: An International Journal, 10(2),105-123. https://doi.org/10.1108/SBM-092018-0066

Dessler, Gary. (2013). Human Resource Management. Edition 13th. Pearson. New Jersey. 
Dharma, Y. (2017). The effect of work motivation on the employee performance with organization citizenship behavior as intervening variable at Bank Aceh Syariah. Emelard Reach Proceedings Series, 1,7-12. https://doi.org/10.1108/978-1-78756-793-100065

Eliyana, A., Ma'arif, S. and Muzakki. (2019). Job satisfaction and organizational commitment effect in the transformational leadership towards employee performance. European Research on Management and Business Economics, 25(3),144-150. https://doi.org/10.1016/j.iedeen.2019.05.001

Franco, M. and Franco, S. (2017). Organizational commitment in family SMEs and its influence on contextual performance. Team Performance Management: An International Journal, 23(7/8),364-384. https://doi.org/10.1108/TPM-05-2016-0020

Furnham, A., \& Gunter, B. (1993). Corporate Assessment: Auditing a Company's Personality. London: Routledge.

Ghashghaeinia, A.R. and Hafezi, S. (2015). Relationship between organizational culture and organizational citizenship behavior among personnel of Islamic Azad University of Fars. J. Appl. Environ. Biol. Sci, 5(11S),131138.https://www.semanticscholar.org/paper/Relationship-between-organizational-culture-and-of-GhashghaeiniaHafezi/72f3a96faa71bee9c8083c48c837ac198d8e469d

Goffee, R. and Jones, G. (1996). What holds the modern company together?. Harvard business review, 74(6),133-148. https://hbr.org/1996/11/what-holds-the-modern-company-together

Harrison, R. (1972). Understanding your organization's character. Harvard Business Review. 50(3), 119128.uulead.org/docs/orgcharacter.pdf

Harwiki, W. (2016). The impact of servant leadership on organization culture, organizational commitment, organizational citizenship behaviour (OCB) and employee performance in women cooperatives. Procedia-Social and Behavioral Sciences, 219(1), 283290. https://doi.org/10.1016/j.sbspro.2016.04.032

Imamoglu, S.Z., Ince, H., Turkcan, H. and Atakay, B. (2019). The effect of organizational justice and organizational commitment on knowledge sharing and firm performance. Procedia Computer Science, 158, 899-906. https://doi.org/10.1016/j.procs.2019.09.129

Jain, A. (2015). Volunteerism and organisational culture. Cross Cultural Management, [online] 22(1), pp.116144. https://doi.org/10.1108/CCM-11-2013-0167

Karinda, J.M.M. and Maski, G. (2016). The Effect Of Organizational Culture, And Entrepreneurship Characteristics Of Knowledge Management On Company Performance (Study On Construction Services Company First Small Qualification Papua In Jayapura). South East Asia Journal Of Contemporary Business, Economics And Law, 11(2), pp.2289-1560. https://seajbel.com/wp-content/uploads/2017/02/BUS-225.pdf

Kinicki, R.K.A. and Kreitner, R. (2014). Perilaku Organisasi: Organizational Behavior. Salemba Empat. Jakarta Selatan.

Kissi, E., Asare, O., Agyekum, K., Yamoah Agyemang, D. and Labaran, M. (2019). Ascertaining the interaction effects among organisational citizenship behaviour, work overload and employees' performance in the Ghanaian construction industry. International Journal of Productivity and Performance Management, 68(7), pp.1235-1249. https://doi.org/10.1108/IJPPM-07-2018-0262

Koopmans, L., Bernaards, C.M., Hildebrandt, V.H., Van Buuren, S., Van der Beek, A.J. and De Vet, H.C. (2014). Improving the individual work performance questionnaire using rasch analysis. Journal of applied measurement, 15(2), pp.160175.https://doi.org/10.1136/oemed-2013-101717.51

Kotter, J. P, and J. L. Heskett. (1992). Corporate Culture and Performance. New York: Free Press.

Kurniasari, I.C., Thoyib, A. and Rofiaty, R. (2018). Peran Komitmen Organisasional dalam Memediasi Pengaruh Kompetensi, Pelatihan dan Budaya Organisasi terhadap Kinerja Perawat. MIX: Jurnal Ilmiah Manajemen, 8(2), pp.352371. http://dx.doi.org/10.22441/mix.2018.v8i2.010

Mondy, R. Wayne and Martocchio, Joseph J. (2016). Human Resource Management, Fourteenth Edition, Global Edition. Pearson Education Limited. London.

Mowday, R. T., Porter, L. W., \& Steers, R.M., (1982). Employee-organization linkages: the psychology of commitment, absenteeism and turnover. New York: Academic Press.

Munawir, M., Raharjo, K., Djalil, M., Syahputra, H., Muslim, B. and Adam, M. (2019). Dimensions of identity strength and organizational citizenship behavior (OCB) in establishing good university governance and performance of religious ideologybased higher educations. Journal of Applied Research in Higher Education, 11(2), pp.250-272. https://doi.org/10.1108/JARHE-07-2018-0115

O'Reilly, C.A. and Chatman, J.A. (1996), "Culture as social control: corporations, cults, and commitment”, in Staw, B.M. and Cummings, L.L. (Eds), Research in Organizational Behavior, JAI Press, Greenwich, CT, 157-200. https://psycnet.apa.org/record/1996-98665-004

Organ, D.W., (1988). Organizational citizenship behavior: The good soldier syndrome. Lexington Books/DC Heath and Com.

Organ, D.W. (1997). Organizational citizenship behavior: It's construct clean-up time. Human Performance, 10(2), pp.85-97. https://doi.org/10.1207/s15327043hup1002_2

Oyewobi, L., Oke, A., Adeneye, T. and Jimoh, R. (2019). Influence of organizational commitment on work-life balance and organizational performance of female construction professionals. Engineering, Construction and Architectural Management, 26(10), pp.2243-2263. https://doi.org/10.1108/ECAM-07-2018-0277

Peters, T. and Waterman, R. (1982). In Search of Excellence. Harper \& Row. New York, NY. 
Putriana, L., Umar, H. and Riady, H. (2015). The impact of organizational culture on job satisfaction, organizational Commitment and job Performance: Study on Japanese Motorcycle Companies in Indonesia. Int J Edu Res, 3, pp.103-14. https://www.ijern.com/journal/2015/September-2015/09.pdf

Raharjo, K., Nurjannah, N., Solimun, S. and Achmad Rinaldo Fernandes, A. (2018). The influence of organizational culture and job design on job commitment and human resource performance. Journal of Organizational Change Management, 31(7), pp.1346-1367. https://doi.org/10.1108/JOCM-07-2017-0286

Sani, A. and Maharani Ekowati, V. (2019). Spirituality at work and organizational commitment as moderating variables in relationship between Islamic spirituality and OCB IP and influence toward employee performance. Journal of Islamic Marketing, 11(6), pp.1777-1799. https://doi.org/10.1108/JIMA-08-2018-0140

Setiawan, L. (2020). The effect of emotional intelligence, organizational commitment on the team performance of hospital officers in South Sulawesi and Central Sulawesi province, Indonesia. International Journal of Pharmaceutical and Healthcare Marketing, ahead-of-print(ahead-of-print). 15(2), pp25-40. https://doi.org/10.1108/IJPHM-04-2019-0028

Shahzad, F., Xiu, G. and Shahbaz, M. (2017). Organizational culture and innovation performance in Pakistan's software industry. Technology in Society, 51, pp.66-73. https://doi.org/10.1016/j.techsoc.2017.08.002

Shim, H., Jo, Y. and Hoover, L. (2015). Police transformational leadership and organizational commitment. Policing: An International Journal of Police Strategies \& Management, [online] 38(4), pp.754-774. https://doi.org/10.1108/PIJPSM-052015-0066

Smircich, L. (1983). Concepts of culture and organizational analysis. Administrative science quarterly, pp.339-358. https://doi.org/10.2307/2392246

Sonnentag, S. and Frese, M., (2002). Performance concepts and performance theory. Psychological management of individual performance, 23(1), pp.3-25. https://doi.org/10.1002/0470013419.ch1

Supriyadi, A., Sanusi, A. and Manan, A. (2017). A study on the performance of manufacturing employees: organizational culture, compensation, organizational commitment, and organizational citizenship behavior. European Journal of Business and Management, 9(6), pp.32-43. https://www.iiste.org/Journals/index.php/EJBM/article/view/35749/36759

Tan, B. (2019). In search of the link between organizational culture and performance. Leadership \& Organization Development Journal, 40(3), pp.356-368. https://doi.org/10.1108/LODJ-06-2018-0238

Trice, H. and Beyer, J.M. (1993), The Cultures of Work Organization, Prentice-Hall, Englewood Cliffs, NJ.

Virtanen, T. (2000). Commitment and the study of organizational climate and culture. Handbook of organizational culture and climate, pp.339-354. Thousands Oaks, CA: Sage

Wandary, W. and Anisah, H.U., (2015). Organizational Culture Values Influences to Lecturer's Organizational Citizenship Behavior at Economics and Business Faculty. Mediterranean Journal of Social Sciences,6(5 S5), pp.236-236. https://doi.org/10.5901/mjss.2015.v6n5s5p236

Zablah, A.R., Franke, G.R., Brown, T.J. and Bartholomew, D.E. (2012). How and when does customer orientation influence frontline employee job outcomes? A meta-analytic evaluation. Journal of Marketing, 76(3), pp.21-40. https://doi.org/10.2307/41714487

Publisher's Note: SSBFNET stays neutral with regard to jurisdictional claims in published maps and institutional affiliations.

\section{(1) (1)}

(C) 2021 by the authors. Licensee SSBFNET, Istanbul, Turkey. This article is an open access article distributed under the terms and conditions of the Creative Commons Attribution (CC BY) license (http://creativecommons.org/licenses/by/4.0/).

International Journal of Research in Business and Social Science (2147-4478) by SSBFNET is licensed under a Creative Commons Attribution 4.0 International License. 